\title{
The Relationship between Credit Default Swaps and Net Portfolio Investments: The Case of Turkey
}

\author{
Mehmet Nar \\ Department of Economics, Faculty of Economics and Administrative Sciences, Artvin Coruh University, Turkey
}

Received February 26, 2021; Revised April 7, 2021; Accepted April 29, 2021

\section{Cite This Paper in the following Citation Styles}

(a): [1] Mehmet Nar, "The Relationship between Credit Default Swaps and Net Portfolio Investments: The Case of Turkey," Universal Journal of Accounting and Finance, Vol. 9, No. 2, pp. 252 - 261, 2021. DOI: 10.13189/ujaf.2021.090215.

(b): Mehmet Nar (2021). The Relationship between Credit Default Swaps and Net Portfolio Investments: The Case of Turkey. Universal Journal of Accounting and Finance, 9(2), 252 - 261. DOI: 10.13189/ujaf.2021.090215.

Copyright $\mathrm{C} 2021$ by authors, all rights reserved. Authors agree that this article remains permanently open access under the terms of the Creative Commons Attribution License 4.0 International License

\begin{abstract}
The aim of this study was to analyze the relationship between credit default swaps and net portfolio investments. Since the series remained stationary at varied levels in the study, the ARDL limit test approach was employed. In the analysis, 10 years of periodical data from 2010 to 2020 were compared. During the implementation of the ARDL limit test, it agreed to add a dummy variable to the model for months 2018M4 and 2020M3 upon the analysis of the CUSUM and CUSUM2 graphics; hence, in the final model, a dummy variable was also included. By means of diagnostic tests administered to the ARDL model that was repeated after the inclusion of the dummy variable, it became evident that the final model met the required hypotheses for the ARDL limit test, and it was thus feasible to interpret the long- and short-term coefficients. As the coefficients of final model attained, it was detected that an increase by $1 \%$ in short term risk premiums reduced current period net portfolio investments by $2.87 \%$. However, it was evident that in the long term credit risk premiums have a small but positive and significant $(\mathrm{p}<0,05)$ effect on net portfolio investments.
\end{abstract}

Keywords Financial Economy, Credit Default Swaps (CDS), Portfolio Investments, Risk Management, Credit Risk

\section{Introduction}

The market is the place in which purchase and sale transactions are realized. Essentially, the market refers to the voluntary exchange of activities related to goods and services. Financial markets, on the other hand, are the mechanisms that can facilitate capital and credit exchanges in the economy. Financial markets are classified into two categories, monetary and capital markets. Monetary markets consist of short-term debt instruments whilst capital markets consist of long-term debt instruments. Capital markets are markets in which, subsequent to first sale, stocks, bonds, and securities are exchanged across investors $[1,2,3,4]$. The main task of the financial system is to provide a flow of funds from the sectors that have a fund surplus to those with a fund deficit. While doing that, the finance sector basically accomplishes two key functions. Firstly, it reduces information processing costs, and, secondly, it diversifies trade while managing risk [5]. Global transformation, having gained impetus particularly in the last two decades, has resulted in growth in financial markets, financial deepening, diversification of investment instruments, and emergence of new derivative instruments. This reality has added even greater value to the management of financial risks in present age. In the aftermath of the global crisis that began in 2008, it was observed that, against the risk of not getting back the credits, modern methods such as the credit default exchange has become popular. In this study, the link between portfolio investments and the CDS concept that relates to effective management of risks was examined. To that end, firstly relevant information on risk management was stated. Common risk types in financial markets, credit risk, concepts related to CDS, and portfolio investments 
were explained. Next, by conducting an ARDL limit test approach, an econometric analysis was performed based on the quarterly data from the 2010-2020 period in the Turkish economy. In the conclusion section, the findings of the analysis were illustrated.

\section{Risk Management in Financial Markets}

The period after the Second World War was an age in which there was no capital mobility, different standards were followed by different countries, geographical barriers played a vital role, central banks controlled the money supply and exchange rates, full-blown financial crises were almost nonexistent, and problems were, compared to today, limited to national markets. However, once the Bretton Woods (fixed exchange rate) system ended in 1971-1972, this structure began to change. Developed continents and countries including North America, Europe, and Japan moved from a fixed exchange rate system to a floating rate of exchange system, and, as a consequence, there was liberalization in capital accounts. Moreover, an offshore flow of financial investments could expand. The 1970s and 1980s were the decades when there was stable growth in the offshore flows of capital. In 1989, when the Berlin Wall fell, a new chapter was opened for financial markets. Specifically with the loosened national control over interest and exchange rates and fast developments in the digital communication area, the outcomes were defined as effective globalization. During this stage local, national, and regional financial markets began to erode. Developing markets and transition economies from the former Soviet Bloc also became a part of financial liberalization endeavors. That being said, through the incentives granted by the IMF and World Bank, foreign capital flows could be transferred to the most remote corners of globe[6,7]. Major developments witnessed in information technologies, primarily in the1990s, are the main reasons for the transformation in the financial domain. Commerce grew exponentially, the new derivative markets were a frequent hot topic, and complex financial instruments were emerging. In parallel with rapid globalization, the concept of financial risk management also became one of the perspectives adopted in the age of modern capitalism $[8,9]$.

An elevated level of uncertainty in financial markets paved the way for a major breakthrough in the field of financial risk management over the last two decades. One of the most important underlying reasons is that the whole world has been facing great financial crises. In the 1980s, the World Bank classified 45 systematic banking crises, and the figure climbed sharply to 63 banking crises in the 1990s. Many of these crises swept away the capital of banking system almost entirely and triggered severe damage in national economies. In that period, many of the rooted and well-established credit corporations such as Barings (1995), Long Term Capital Management (1998), Enron (2001), Worldcom (2002), Parmalat (2003), and Lehman Brothers (2008) collapsed. Considering the peak level that global financial markets had reached, problems born out of the failure in financial risk management also came into focus. Since traditional and other risk measuring methods failed to be effective in practice, a search for new approaches accelerated [6,10]. Until the financial crisis of 2008, the popular notion was to consider periodical scores issued by credit rating agencies when investment decisions were evaluated. Yet, it became apparent that, in times of crisis, these scores failed to provide an updated picture of the current situation; hence investors began to use new indicators such as the CDS concept in measuring credit risk[11].

The literal definition of risk is a concept that indicates potential dangers likely to emerge in the future. The concept entails two opposite sides, e.g., winning or losing. Risk management, on the other hand, offers guidelines related to the policies and procedures that should be implemented to prevent or minimize potential risks born out of current risks. To get the maximum benefit from their investments, first, investors should detect the potential risks that their investment could face. Next, by making use of the kind of instruments and methods that can be called as proactive risk management against the risks, the aim is to make the commerce more visible. Thus, the intention is to minimize current risks $[12,13]$. The primary goal of CDS transactions, which have gained wider recognition lately, is also to accurately detect risk and manage it correctly [14].

The major risk types that could be detected in financial markets can be classified as follows: (i) Market risk is the risk type caused by the floating that results from the falling and rising of market prices. These kinds of risks are related to the changes detected in the prices of key variables such as stock prices, interest rates, exchange rates, commodity prices and credit prices. (ii) Liquidity risk is the risk type that takes form in two ways including asset liquidity risk which indicates the loss that emerges when assets are converted into cash or converted into cash in a value far below its market price and funding liquidity risk which the kind of risk related to delayed payments because of instabilities experienced in the cash flows of companies. (iii) Operational risk is the risk of a change in value caused by the fact that actual losses differ from expected losses. They emerge from people, systems, and internal and external events. Faults in market entry, purchase and sale errors, the using of incorrect methods, fraud, and risks that emerge due to violation of legal contracts are related to operational risk. (iv) Value at risk (VAR) has been a major risk management method over the last two decades. In the early stage, it was designed as a criterion for market risk, but it has subsequently become an instrument used to efficiently define risk via one single 
quantity in the financial domain. VAR measures the expected maximum within a specific confidence interval range or, to put it another way, it indicates risk exposure value. (v) Credit risk: measures the probability of a lapse into default in capital and/or interest payments when the borrower fails to abide by contractual terms in a timely fashion. (vi) Miscellaneous risks include interest rate risk, contagion risk, volatility risk, purchasing power risk, regulatory risks, country risk, and similar risks that unravel the economic, social, and political structure of borrower state. In addition, risks such as legal risks that stem from ineffective legal regulations can also be classified in the miscellaneous risks category. Furthermore, the credit risk concept, being a type of risk that also affects market risk, is a topic worthy of careful analysis $[5,15,16,17,18]$.

\subsection{Credit Risk}

The risk that refers to the probability of borrowers not paying back the credits taken is called credit risk. In essence, credit risk is the risk type that banks, insurance companies, pension funds, foundations, and investors in general can experience. In financial markets, risks are classified as systematic and nonsystematic risks. The exchange rate risk and the interest rate risk that stems from cyclical floating are systematic risks. Nonsystematic risks are entity-specific risks such as the assets of financial institutions, personnel quality, customer quality, and organizational capability. Credit risk, liquidity risk and operational risks are among the nonsystematic risks [19].

In this era, credit risk is one of the greatest risk types witnessed in financial markets. The global crisis in 2008 that broke out in the USA, 2009 credit crisis in Dubai, and the national debt crisis in 2010 in Europe are among the most salient examples. Credit risk, just like market risk, is one of main types of risks that investors can face. Credit risk is the risk type that creditors can face due to the failure of borrowers to abide by contractual terms that may result in losses.. Another dimension of credit risk takes place at the point of expanding risk and negatively affects the market risk due to value change. On the other hand, a different dimension of credit risk is counter party risk that emerges due to derivative transactions. Since conducted operations are derivative transactions, in this form of credit risk there is a strong likelihood that both parties of the contract could lapse into default because every one of the parties is a buyer and also a seller. To put it a different way, each party is simultaneously the borrower and the creditor. As the 2008 global financial crisis swiftly expanded to all financial markets soon after it occurred in the USA, counter party credit risk became even more concerning. In the said period, the bankruptcy of rooted investment corporations such as Lehman Brothers which was founded in 1850 , and the collapse of giant financial groups such as Bear Stearns, AIG, Fannie Mae, Freddie Mac, Merrill Lynch, and the Royal Bank of Scotland indicated catastrophic years in derivative markets in relation to risk management; hence, among the participants operating in financial markets, credit risk became synonymous with a giant threat and considered a major financial risk type $[10,16,20]$.

In reducing or preventing credit risk, the initial requirement is accurate measurement of the risk, and, to that end, a number of models and methods have been developed. Traditional methods conduct risk assessment on the basis of $5 \mathrm{C}$ limits: economic conditions, character, capital, capacity, collateral, etc. In return, modern methods conduct risk assessment on the basis of different methods such as Merton-based models, credit rating agencies, and the historical default rate approach. Merton-based models take into account the scarcity of assets and the liabilities of a given company. Through these figures, the model computes the risk of a lapse into default for a company. The historical default rate approach computes credit risk by evaluating past data. Risk analysis pertaining to credit rating agencies such as Fitch, Moody, Standard \& Poors is established upon statistical criteria modeled on letters and numbers. The aim is to make credit risk visible for the governments and financial and nonfinancial companies. To illustrate, the Standard \& Poors rating scale is based on a scoring system from a maximum level of AAA to lower scores as $\mathrm{AA}, \mathrm{A}, \mathrm{BBB}, \mathrm{BB}, \mathrm{B}, \mathrm{CCC}, \mathrm{CC}, \mathrm{C}$, and $\mathrm{D}$. In addition to traditional and modern methods, another risk-measuring method is the credit portfolio risk measuring model. The specific feature of this model is measuring and demonstrating the credit risk, or to put it another way, the potential loss that portfolio would be exposed to within a predetermined confidence interval (generally one year) $[21,22,23]$.

Another method in practice is Basel Standards. The Basel BIS Bank of International Settlements, established in 1930, is among the major international finance agencies. Driven by the motto that financial agencies, banks in particular play a critical role in global integration, and BIS aims to develop common regulations for their operations. To that end, the Basel Committee was founded in 1974. The Committee aimed to form uniform standards in asset and off-balance transactions of banks. Thus, solving bankrupt bank problems would also be viable. In order to meet the capital requirements of banks, it was resolved that capital adequacy ratio would be a minimum of eight percent for current assets, and these principles, called Basel-I resolutions, were declared in 1988. Financial risks due to derivative products and crises in banking sector facilitated the operation of Basel II. In order to perform transactions in a more transparent setting, both for the credit borrowers and creditors, Basel II implemented basic accounting techniques in financial markets, and it aimed to protect the capital structures of the banks against risks. 
To ensure that corporations used the credits they had in line with objectives, more rigid and deterrent regulations were implemented. Basel III was introduced in 2010 in an attempt to alleviate the adverse effects of the 2008 global crisis. In that, the objectives of banks were set including strengthening the capital structures, decreasing leverage rations, the supervision of banks, implementing stronger market discipline, and creating a countercyclical capital buffer in accordance with minimum capital requirements. The goal of a cyclical capital buffer is to predict the signals of crisis via specific instruments and increase the amount of current capital against the crisis. In short, the objective is to build a buffer against the crises before they occur. The key instruments of a cyclical capital buffer are basic models such as CDS premiums (also known as credit default swaps) and profitability rates [21,22,23].

\subsection{CDS Premium}

Credit default swaps, or CDS, are credit derivative contracts that enable investors to swap credit risk on a company, country, or other entity with another counterparty [24]. Credit default swaps (CDS) are the methods generally used generally to minimize credit risk. CDS contracts are signed between CDS companies and investors [25]. A credit default swap is a contract or financial derivative that transmits the credit risk of an investor to a different investor in return for a certain amount of premium. If the creditor suspects that the borrower could lapse into default and fail to pay back the credit, creditor can employ CDS to prevent such risks. In other words, the creditor purchases insurance against the risk of the borrower lapsing into default; thus, CDS is a form of insurance policy. In the contract, one of the parties is the lender creditor. The other party is a type of insurance company that guarantees the payment of the receivable in case the debtor fails to reimburse. The creditor that purchases CDS, mostly in quarterly periods, pays a premium to the insurance company selling CDS, thereby warranting its receivable $[24,26]$.

To illustrate, a foundation purchases debt security (bonds) issued by Greece and then lends money to Greece with interest for a specific length of time. With the expiration of the term, the creditor aims to reimburse its capital with its accumulated interest, but, if the foundation suspects that Greece could fail to pay back the costs of bonds, then it transfers these bonds to a foundation that performs the CDS transaction. A specific amount of premium is paid to the foundation conducting the CDS transaction. Thus, if Greece fails to pay back its debt at the expiration of the term, it has purchased a payment guarantee from the CDS company. The premium paid by the said foundation to the CDS company is then called the CDS premium (risk premium). CDS risk premiums that must be reimbursed for the bills payable exported by Turkey can be seen in Graphic 1. Accordingly, the CDS premium for Turkey was at its lowest level in January 2020 (238). In May, it scored the maximum level (621). As of December 2020, the CDS premium for Turkey was 363. Other CDS premium scores are follows: Germany, 12; USA, 16; England. 28; Russia, 125; Italy, 212; Greece, 373; and Argentina, 650.

As of November 2020, Turkey's CDS premium was 372 points, but what does this actually mean? This ratio shows that an investor owning a debt security valued at 100 dollars (bonds) issued by Turkey has to pay that amount of premium to the CDS company against the risk that Turkey could fail to pay its debt back. To compute the risk, the premium payable to the insurer, the CDS premium must be divided by 100 . A 100 dollar bond exported by Turkey has a CDS value of $372 / 100=3.7$ dollars. In that case, a creditor purchasing Turkish bonds and wanting to secure them via CDS warranty has to pay a risk premium of 3.7 percent of the value of the bonds. Since risk premium of Turkey is high, there is a corresponding peak in its borrowing costs. As a result of a rise in borrowing costs, exchange rates are over-appreciated and inflation soars. Since interest is a cost factor, an increase in cost inflation is an inevitable result. However, since CDS premiums change daily on the market, spontaneous falls and rises are reflected in the markets. Therefore, in essence, CDS risk premiums are an indicator that measures credibility of countries. Major factors impinging upon CDS risk premium are as follows:

1. Economic conditions in the country,

2. Risks that are born out of global actions,

3. Frequency of unforeseen hypotheses,

4. Volatility of financial markets,

5. Variations in macroeconomic policies $[27,28,29]$.

In Turkey, a rise in risk premium could first result in worsened key macroeconomic problems such as unemployment and inflation. If foreign investors demand higher interest in the face of a higher risk before investing in a risky country, then there is a significant level of rise in borrowing costs. Therefore, credit risk is, in some sense, the main determinant of "country risk". However, "country risk" does not merely consist of economic risks such as credit risk, debt burden, or default rate. Public and political instability, negative government regulations (expropriation or capital controls), and a corrupted legal system are other factors that form country risk [30]. As a result, in comparison to credit risk, the country risk concept defines a much wider space.

\section{Portfolio Investments}

Portfolio investments that escalate in parallel with globalization have become transferable from one country to another by just one click. From that aspect, hot money flows represent the unstable dimension of global financial flows. Although financial flows can be operated through 
key forms such as direct investments, portfolio investments, remittances, debt related flows, and state development grants, the main factor within this classification is portfolio investments [31].

What is meant by portfolio investments is that investors direct their investments to stocks, bonds exported by public, and private institutions and financial instruments. In this way, the reducing of financial risk can be viable while capital holders can also attain income such as interest and premiums. Moreover, miscellaneous financial instruments like bank deposits, one-year maturity syndication credits, and repo transactions can also be classified as short-term capital movements. That being the case, speculative capital investments are short term portfolio investments or, in other words, hot money flows that are primarily based on interest and currency arbitrage $[10,44]$.

The IMF's initiatives to annul capital controls at the onset of the 1990s further heightened the mobility of portfolio investments. Thus, it was seen that in the 1990s in international capital markets, there was a sudden and radical transformation never witnessed before. In increasing international hot money flows, there were significant increases (idle funds) that triggered the deterioration of the balance of payments and resulted in a greater deterioration in capital accounts compared to current accounts. Budget deficits also expanded at a significant rate. Similar experiences occurred in Mexico in 1994-1995, in southeast Asia in 1997, in Russia in 1998, in Brazil in 1999-2002, and in Turkey and Argentina in $2000-2002$ to the 2008 global crisis [32,33].

The kind of approaches that tout the benefits of hot money flows note that, in developing countries, hot money plays a vital role in closing the savings gap because money flows reduce interest rates, and reduced interest rates can thus result in higher investments. That exchange enables the countries to develop much faster. That being the case, hot money flows directed to developing countries are deemed vital, not only to secure macroeconomic stability but also to sustain structural adjustment programs. Further to that, commercial and financial liberalization lowers risk perception in developing countries, and that also leads to a significant fall in the external debt burden. By means of confidence in the international zone, it is clear that a great number of developing countries develop a positive economic view. Opponents argue that all the experiences to the present have shown that speculative capital flows caused more harm than good because portfolio investments flowing into a country for a short-term income gain leave the country soon after signs of crisis appear, thereby resulting in a wide range of macro-economic problems including financial crises, deficits in the balance of payments, debt crises, and excessive appreciation in exchange rates[7,34,35,36].

Portfolio investments tend to follow a trend that increases during the expansion periods of economies and decreases in times of crisis. Risks and uncertainties that are bound to the political, economic, and legal performance of a given country play a determinant role in such type of investments. In an attempt to nullify risk, investors prefer to make use of modern methods and Credit Default Swaps is among the most popular methods amongst them [25].

\section{Literature Review}

In the relevant literature, there are a scarcity of studies focusing on the relationship between portfolio investments and CDS data. Instead, a vast majority of available studies have mostly analyzed the links between CDS data and the stock exchange including one by Fung et al. (2008) in which the relationship between USA stock exchanges and CDS rates for the period from 2001 to 2007 was analyzed. Results of this analysis clearly demonstrate the causality relationship between bourse activities and CDS premiums. Any increases or decreases in CDS premiums play a role in pricing within bourse and volatility values. In a study by Marzano et al. (2014), they concluded that in the United Kingdom, USA, and Japan, the CDS variable can affect stock prices by a ratio of $71 \%$. In the aftermath of the 2008 global financial crisis, Cho \& Rhee (2014) conducted a study of countries including China, Japan, South Korea, and Singapore. According to their results, a decrease in CDS premiums plays a critical role in direct and indirect capital input. In a large-scale study conducted by Stolbov (2014) there is a comparison between BRICS countries and European states. The study examines the causal relationships between sovereign credit default swaps (CDS) prices for BRICS and the most important EU economies (Germany, France, the UK, Italy, Spain) during the European debt crisis. Findings of this research reveal the limited dependence of the BRICS CDS (especially in the case of Brazil, China, and South Africa) on the EU CDS prices. The same study also supports the view that the European debt crisis has so far had a limited non-EU impact in this market $[11,37,38,39]$.

A different perspective was presented by an analysis related to Turkey by Özkaplan (2011) for the period of 2002-2010. In this analysis, CDS premiums were compared to various financial indicators such as the Dow Jones Index, the IMKB (Istanbul Stock Exchange) 100 Index, and a currency basket. According to the results of this analysis, a causality relationship exists between CDS premiums and value of financial assets. In the research by Emir et al. (2013), the relationship between direct foreign investments and country risk as well as macroeconomic variables were investigated. According to the result of this analysis on the 1992-2010 period, there is a unidirectional causality relationship from country risk towards direct foreign investments. Topal \& Gül (2016) analyzed the relationship between economic risk and direct foreign investments and concluded that, in Turkey, an increase in 
foreign capital investments led to a decrease in country risk. Başarır \& Keten (2016) drew a comparison between the CDS data of 12 select states and the Stock Exchange Index and Exchange rate values of the2010-2016 period. At the end of this study, a unidirectional causality relationship was detected from CDS premiums towards exchange rates. For the period between January 2005-September 2017 in Turkey, Kahilogullari (2018) examined the relationship between CDS premiums and direct and indirect investments by employing ARDL (Autoregressive Distributed Lag Model). The results of this study suggest that, in Turkey, there is not a long- and short-term relationship between credit default swaps (CDS) and direct foreign investments. Nevertheless, between portfolio investments and CDS premiums, a long and short-term relationship was identified. In a similar study [11], a relationship between CDS premiums and net portfolio investments was analyzed. In this study that utilized quarterly data from the 2010-2018 period, it was discovered that a cointegration relationship prevailed between CDS premiums and portfolio investments. In other words, it can be argued that CDS is the cause of portfolio investments $[11,38,39]$.

\section{Research Method}

In this study, the aim was to demonstrate the relationship between Turkey's credit default risk premiums (CDS) and net portfolio investments (NPI). To achieve this, first, the stationary of the series was examined by administering unit root tests. Upon verifying that the series offered stationary requirement at different levels, it was decided to implement the ARDL limit test. The ARDL limit test method allows the examination of a cointegration relationships among stationary variable at different levels provided that I(2) is not. Therefore, at the start, stationary of the variables used in the study was analyzed via the ADF and PP unit root tests. Next, by estimating an unconstrained error correction model, shortand long-term coefficients were examined as well asl their significance. Variables listed in Table 1 were also included in the research.

Table 1. Variables Used in the Research

\begin{tabular}{ccc}
\hline Variable & Explanation & Period \\
\hline CDS & Credit Default Risk Premiums & 2010M3-2020M9 \\
NPI & Net Portfolio Investments & 2010M3-2020M9 \\
\hline
\end{tabular}

\section{Empirical Findings}

In Table 2, the ADF and PP unit root tests of the variables used in the model can be seen. As can also be seen in Table 2, in both of the two unit root tests, the credit default risk premium series are not stationary at the level but rather become stationary in the first differences. The net portfolio investment series, however, is stationary at the level. Since the variables were stationary at different levels, it was deemed appropriate to analyze their cointegration relationship via employing the ARDL limit test.

Prior to examining the cointegration relationship between ARDL limit test and variables, an ARDL estimation without constant term was implemented automatically according to SIC criteria. The results of the ARDL limit test are as displayed in Table 3 where the optimal lag length computed automatically according to SIC value is $(1,3,2)$. The computed $F$ value $(F=32,92491)$ is above the critical value at a significance level by $1 \%$ and $5 \%$. Hence, the presence of a cointegration relationship was then validated. Validating the finding regarding the presence of an obtained cointegration relationship evidences the presence of a long-term balance relationship. As a consequence, a coefficient estimation that demonstrates short- and long-term relationships between variables should be conducted.

Table 2. Unit Root Tests

\begin{tabular}{cccccccc}
\hline & \multicolumn{2}{c}{ Constant } & \multicolumn{2}{c}{ Constant \& Trend } & \multicolumn{2}{c}{ Without Trend \& Constant } \\
& & PP* & ADF** & PP* & ADF** & PP* & ADF** \\
\hline CDS & $\mathrm{t}$ & $-1,4345$ & $-1,7146$ & $-2,9174$ & $-3,0622$ & 0,7840 & 0,0749 \\
& & 0,5634 & 0,4215 & 0,1607 & 0,1201 & 0,8812 & 0,7048 \\
& $\mathrm{p}$ & $(4)$ & $(0)$ & $(1)$ & $(0)$ & $(12)$ & $(0)$ \\
$\mathrm{d}(\mathrm{CDS})$ & $\mathrm{t}$ & $-13,7227$ & $-13,1694$ & $-14,0622$ & $-13,1906$ & $-13,5315$ & $-13,1527$ \\
& & 0,0000 & 0,0000 & 0,0000 & 0,0000 & 0,0000 & 0,0000 \\
& $\mathrm{p}$ & $(9)$ & $(0)$ & $(10)$ & $(0)$ & $(8)$ & $(0)$ \\
\hline $\mathrm{NPI}$ & $\mathrm{t}$ & $-9,7573$ & $-9,7633$ & $-9,8857$ & $-9,9243$ & $-9,7297$ & $-9,6803$ \\
& & 0,0000 & 0,0000 & 0,0000 & 0,0000 & 0,0000 & 0,0000 \\
$\mathrm{~d}(\mathrm{NPI})$ & $\mathrm{p}$ & $(5)$ & $(0)$ & $(6)$ & $(0)$ & $(3)$ & $(0)$ \\
& $\mathrm{t}$ & $-64,2379$ & $-8,7978$ & $-63,9475$ & $-8,7240$ & $-62,9028$ & $-8,8347$ \\
& $\mathrm{p}$ & 0,0001 & 0,0000 & 0,0001 & 0,0000 & 0,0000 & 0,0000 \\
\hline
\end{tabular}

* Parenthetical values indicate band length detected according to Bartlett Kernel.

** Parenthetical values indicate lag length detected automatically according to the SIC value. 
Table 3. Results of ARDL Limit Test

\begin{tabular}{ccc}
\hline Model & ARDL \\
\hline Optimal Delay (Auto SIC) & & $1,3,2$ \\
\hline F & 32,92491 \\
\hline Critical Value (\%1) & I (0) & 3,88 \\
& I (1) & 5,3 \\
\hline Critical Value (\%5) & I (0) & 2,72 \\
& I (1) & 3,83 \\
\hline
\end{tabular}

Subsequent to detecting the presence of a cointegration relationship in order to test the validity of this relationship, results need to be examined by administering a range of diagnostic tests. Findings of the diagnostic tests are as exhibited in Table 4 and Figure 1. As seen in Table 4, there are no autocorrelation or variance problems in the model ( $p>0,01)$. Furthermore, there is no lack of normal distribution of residuals $(p>0,01)$. At the end of the Ramsey-RESET test, it became clear that, in the model, there is no identification error $(\mathrm{p}>0.01)$. CUSUM and CUSUM2 graphics also reveal that they fit in a $5 \%$ confidence range, and the estimated parameters are stable (Figure 2).
Table 4. Results of Diagnostic Tests

\begin{tabular}{|c|c|c|}
\hline Test & Statistics & Result \\
\hline Breusch-Godfrey LM & $\begin{array}{c}\chi^{2}(2)=3,685711 \\
(0,1584)\end{array}$ & $\begin{array}{c}\text { No autocorrelation } \\
\text { problem }\end{array}$ \\
\hline DW & $\mathrm{DW}=2,089902$ & \\
\hline Breusch-Pagan-Godfrey & $\begin{array}{c}\chi^{2}(8)=13,16745 \\
(0,1062)\end{array}$ & $\begin{array}{c}\text { No changing } \\
\text { variance problem } \\
\text { (constant variance) }\end{array}$ \\
\hline ARCH Test & $\begin{array}{c}\chi^{2}(1)=0,32756 \\
(0,5671)\end{array}$ & \\
\hline Jarque-Bera & $\begin{array}{c}\mathrm{JB}=0,467836 \\
(0,791427)\end{array}$ & $\begin{array}{c}\text { Residuals are } \\
\text { normal distributed }\end{array}$ \\
\hline Ramsey-RESET & $\begin{array}{c}\mathrm{t}=2,040771 \\
(0,0536)\end{array}$ & $\begin{array}{c}\text { No model } \\
\text { identification error } \\
\end{array}$ \\
\hline CUSUM ve CUSUM $^{2}$ & & $\begin{array}{c}\text { Within } 5 \% \\
\text { confidence interval } \\
\text { Estimated } \\
\text { parameters are } \\
\text { stable, and there is } \\
\text { no structural break * }\end{array}$ \\
\hline $\mathrm{R}^{2}$ & 0,140215 & \\
\hline Adj. $R^{2}$ & 0,088331 & \\
\hline
\end{tabular}

*:At the end of CUSUM and CUSUM2 tests for months 2018M4 and $2020 \mathrm{M} 3$ when there was a break, a dummy variable was integrated into the model.

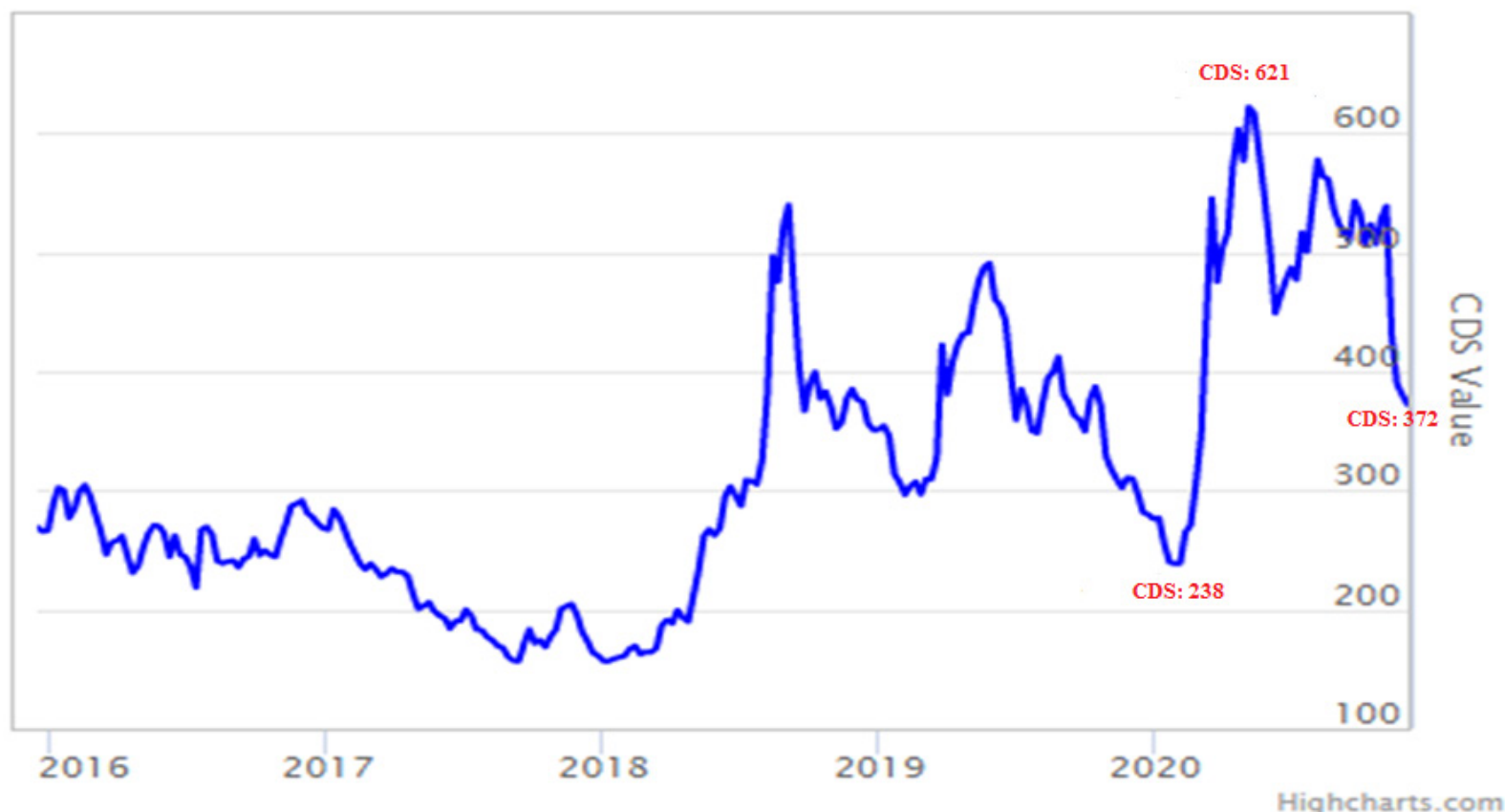

Source: [29].

Figure 1. Turkey-5years CDS 

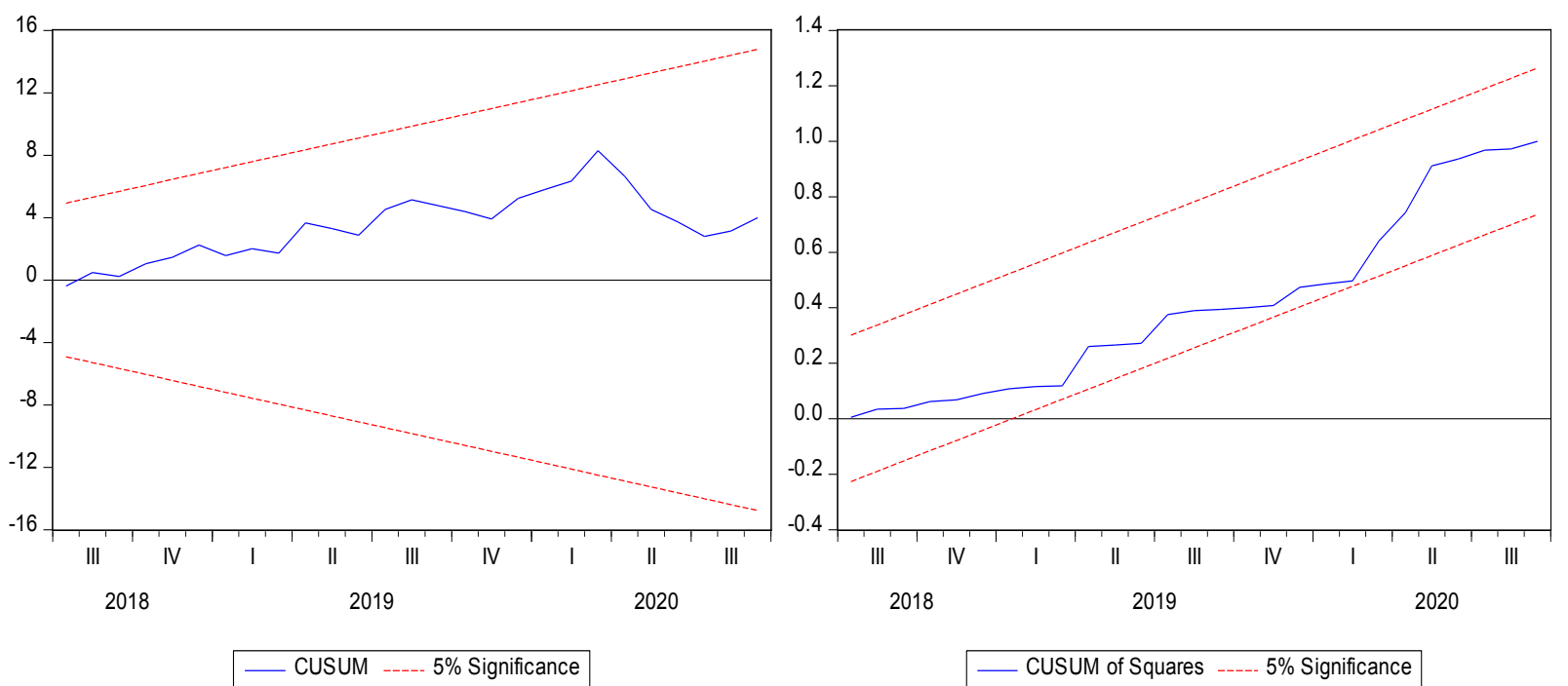

Figure 2. CUSUM and CUSUM2 Graphics

Upon testing the validity of the diagnostic tests administered for the ARDL model, it was concluded that the estimated short- and long-term coefficients are reliable. Table 5 presents the short- and long-term estimation coefficients. Short term results reveal that the model coefficients of the error correction term $(-0,87505)$ have, as demanded, a negative sign, ranging between (-1) and (0) and maintaining statistical significance $(\mathrm{p}=0.000<0.05)$. Therefore, it can be argued that the error correction mechanism functions well. 1 unit of deviation emerging in the short term is removed approximately 1.14 periods later $(1 /-0,87505)$. In other words, deviations detected in the short term are removed in the long term. As the coefficients were reviewed, it was detected that, in the short term, an increase by $1 \%$ in the risk premiums three periods earlier can decrease net portfolio investments during the current period by a ratio of $2.87 \%$. In the long term, however, it was detected that credit risk premiums have a small and yet positive and significant $(\mathrm{p}<0.05)$ effect on net portfolio investments.

Table 5. Short- and Long-Term Estimation Findings

\begin{tabular}{ccccc}
\hline Variable & Coefficient & $\begin{array}{c}\text { Standard } \\
\text { Error }\end{array}$ & $\mathrm{t}$ & $\mathrm{p}$ \\
\hline \multicolumn{5}{c}{ Long Term } \\
\hline CDS & 0,560975 & 0,270751 & 2,071926 & 0,0405 \\
DUMMY & $-1677,179$ & 1111,690 & $-1,508676$ & 0,1341 \\
\hline \multicolumn{5}{c}{ Short Term } \\
\hline D(CDS) & 0,99692 & 1,35167 & 0,73755 & 0,46230 \\
D(CDS(-1)) & 1,80719 & 1,35401 & 1,33469 & 0,18460 \\
D(CDS(-2)) & $-2,87845$ & 1,35140 & $-2,12997$ & 0,03530 \\
D(DUMMY) & 435,111 & 390,004 & 1,11566 & 0,26690 \\
D(DUMMY & 1027,67 & 408,958 & 2,51290 & 0,01330 \\
(-1)) & $-0,87505$ & 0,08730 & $-10,02386$ & 0,00000 \\
CointEq(-1)
\end{tabular}

\section{Conclusions}

Credit risk management is a serious problem of the modern age. Difficulty in obtaining real-time information about the borrower, the problem of moral hazard, default risk, an atmosphere of uncertainty, financial crises, and various other factors make credit risk management even more difficult. Therefore, instruments like credit default swaps and practices that aim to manage credit risk effectively have become more frequently employed after the 2008 global financial crisis. Investors in particular purchase a CDS contract from a CDS company operating in credit default exchange markets (credit default swap market). Thus, a type of insurance has been purchased against the risk of not receiving the credit back. In return for the insurance premiums they paid, they transfer the current risk to the insurer. In such ways, the CDS acts as a vital indicator that enables a more effective allotment of credits and reveals the risk exposure values of investors in a clearer, simpler, more transparent, and reliable format.

This analysis demonstrates a major causality relationship exists in Turkey between CDS premiums and portfolio investments in the short term. An increase in CDS premiums decreases portfolio investments whereas a decrease in CDS premiums results in an increase in portfolio investments. In the long term, however, there is a limited level of relationship between CDS premiums and portfolio investments. This is a finding that reminds us of the reality that Turkey is growing only by means of short-term external borrowing. In fact, one of the biggest problems in the Turkish economy is that the country is growing, not by means of its equities, but rather by means of debt (short term). A closer look at the recent history of Turkey also indicates that in the background to economic growth dynamics lie the expansionary monetary policies of developed countries. To sum up, when there is decline in US growth expectations, nonfarm employment and the 
consumer confidence index declines and inflation rates fall; thus, a feasible setting for FED can be created. The FED performs the expected interest discount. Finally, since USA state bonds fail to meet the expectations of international investors, large quantities of portfolio investments, primarily pension funds and hedge funds, shift towards developing countries where interests are higher as can clearly be seen in the cases of Argentina, Brazil, South Africa, and Turkey. Nonetheless, since risk indicators in Turkey such as CDS are high, it is clear that portfolio investments enter to our country at high costs. Thus, the borrowing costs in Turkey are high. Instead of receiving funds that are aimed for long-term development from international foundations (IMF), opting for short-term credits from foreign finance companies (bankers) also put the sustainability of debts into serious trouble. Additionally, the weakening of the global risk appetite and a significant rise in the volatility of financial markets also result in a heavy outflow of capital towards developing countries. Therefore, in addition to state policies, adversities due to global trends also play a role in greater increases in CDS price in Turkey [30,40].

The USA bank Morgan Stanley describes countries having high inflation, a high current account deficit, and high financing expenses as a fragile quartet. It has been noted that in these countries including Turkey, India, Indonesia, South Africa, and Brazil, economic risks are high. In an attempt to lower risks, establishing political and economic stability and preventing the imports, luxury consumption, splurging and squandering that have reached critical levels are suggested. It is deemed vital to implement structural reforms in the domains of law, politics, economy, education, competency, technology, and human capital in a method distant from populism. Reducing the public sector borrowing requirement, supporting $\mathrm{R} \& \mathrm{D}$ activities and the production of high value added products, opting for long-term borrowing rather than short term debts, improving the investment climate, and applying incentives for export have great value. Furthermore, the risk measurement of credit rating agencies should be supervised or else risk indicators can be misused in a way that targets a specific country or region, and indicator values can evolve into a tool for developed countries to freely exercise the policies they want to impose $[41,42,43,45]$.

\section{REFERENCES}

[1] Downes, J., Goodman, J. Dictionary of Finance and Investment Terms. Barron's Educational Series, 1998.

[2] Hahnel, R. The ABCS of Political Economy: A Modern Approach. PlutoPress, 2002.

[3] Kocaman, Ç.B. Financial Markets. Siyasal Kitabevi, 2003.
[4] Williams, R.T. An Introduction to Trading in the Financial Markets. Academic Press, 2011.

[5] Haan, J.D., Oosterloo, S., Schoenmaker, D. European Financial Markets and Institutions. Cambridge University Press, 2009.

[6] Barton, D., Newell, R., Wilson, G. Dangerous Markets: Managing in Financial Crises. Wiley, 2003.

[7] Nar, M. "Capital controls, new IMF policies and the practice of Turkey". American Journal of Economics, vol.4, no.6, pp. 226-239, 2014. doi:10.5923/j.economics.20140406 .02

[8] Kyrtsis, A. Financial Markets and Organizational Technologies: System Architectures, Practices and Risks in the Era of Deregulation. Palgrave Macmillan, 2010.

[9] Nar, M. "R\&D expenditures as a tool for tax planning". The Journal of International Social Research, vol.8, no.37, pp. 925-940, 2015.

[10] Nar, M. "Credit risk management in the financial markets" Journal of Applied Finance \& Banking, vol.4, no.4, pp. 107-125, 2014

[11] Yıldırım, H., Sakızc1, M. "The relationship between portfolio investment and CDS: The case of Turkey". Turkish Studies-Social Sciences, vol.14, no.5, pp. 2777-2792, 2019.

[12] Silvia, J.E. Dynamic Economic Decision Making: Strategies For Financial Risk, Capital Markets and Monetary Policy. Wiley, 2011.

[13] Wild, S.E. Webster's New World Law Dictionary. Wiley, 2006.

[14] Kobeissi, Y.H. Multifractal Financial Markets: An Alternative Approach to Asset and Risk Management. Springer, 2013.

[15] Duffy, D.J., Germani, A. Financial Markets. Wiley, 2013.

[16] Gregory, J. Counterparty Credit Risk: The New Challenge For Global Financial Markets. Wiley, 2010.

[17] Satchell, S. Forecasting Expected Returns in the Financial Markets. Elsevier. 2007.

[18] European Youth Parliament. "Tbilisi Resolution Booklet, 86th International Session of the European Youth Parliament EU", Online available fromhttp://issuu.com/zura giorgobiani/docs/resolution-bo oklet

[19] Sweeting, P. Financial Enterprise Risk Management. Cambridge University Press, 2011.

[20] Shibo, B., Xiaoyang, Z. Dynamic Asset Allocation With Credit Risk. In: D.Wu, (ed.), Quantitative Financial Risk Management. Springer, 2011.

[21] Gup, B.E. Capital Markets Globalization and Economic Development. Springer, 2005.

[22] Malz, A.M. Financial Risk Management: Models History and Institutions. Wiley, 2011.

[23] Saunders, A., Allen, L. Credit Risk Measurement in and Out of the Financial Crisis: New Approaches to Value at Risk and Other Paradigms. Wiley, 2010. 
[24] Kuepper, J., Scott, G. "Credit Default Swap (CDS) Definition: What is a Credit Default Swap", Online available from https://www.investopedia.com/terms/c/credit defaultswap.asp.

[25] Sornette,D., Ivliev, S. Market Risk and Financial Markets Modeling. Hilary Woodard Press, 2012.

[26] Tamakoshi, G., Hamori, S. Credit Default Swap Markets İn the Global Economy. Routledge, 2018.

[27] Eğilmez M. "Currency, Interest, GDS, BIST, Rating, CDS", Online available fromhttps://www.mahfiegilmez.com/2013/ 07/kur-faiz-dibs-bist-reyting-cds-hepsi.html

[28] Pan, J., Singleton, K.J. "Default and recovery implicit in the term structure of sovereign CDS spreads". The Journal of Finance, vol.63, no.5, pp. 2345-2384, 2008.

[29] World Government Bonds. "Turkey 5 Years CDS: Historical Data", Online available from http://www.world government bonds.com/cds- historical-data/ turkey/5-years

[30]Nar, M. "Causality relationship of consumer loans with inflation and current account deficit: The case of Turkey". Turkish Studies, vol.15, no.7, pp. 3009-3024, 2020 DOI:http://dx.doi.org/10.7827/TurkishStudies.45493

[31] Soubbotina, T.P. Beyond Economic Growth: An Introduction to Sustainable Development. The World Bank, 2004.

[32] Haldane, A.G. Fixing Financial Crises in Thetwenty-First Century. Routledge, 2004.

[33] Vague, R. A Brief History of Doom: Two Hundred Years of Financial Crises. University of Pennsylvania Press, 2019.

[34] Agenor, P.R., Montiel, P.J. Development Macroeconomics. Princeton University Press, 2015.

[35] Moschella, M. Governing Risk: The IMF and Global Financial Crises. Palgrave Macmillan, 2010.
[36] Rother, B. The Determinants of Currency Crises: A Political Economy Approach. Palgrave Macmillan, 2009.

[37] Fung, H.G., Sierra, E.G., Yau, J., Zhang, G. "Are the us stock market and credit default swap market related? Evidence from the cdx indices". The Journal of Alternative Investments, vol.11, no.1, pp. 43-61, 2008.

[38] Kahilogullari, A. "Relationship between credit default swaps, direct foreign investments and portfolio investments: Time series analysis for Turkey". Prizren Social Science Journal, vol.2, no.3, pp. 50-62, 2018.

[39] Stolbov, M. "The causal linkages between sovereign CDS prices for the BRICS and major European economies". Economics E-Journal, vol.8, no.1, pp.1-43, 2014.

[40] Güven, G. "Short-Term External Debt With Growing Turkey" Online available from https://www.gazeteduvar.co m.tr/forum/2019/09/21/kisa-vadeli-dis-borclanma-ile-

[41] Kavruk B. "The Importance of CDS and Turkey", Online available from https://www.sanalbasin.com/bekir-kavruk-cd sin-onemi -ve-turkiye-32062866/

[42] Morgan Stanley. Global EM Investor The Fragile Five. Morgan Stanley Research, Academic Press, 2013.

[43] Nar, M., Nar, M.Ş. “An updated assessment of the OECD's quality of life index". Problemy Ekorozwoju-Problems of Sustainable Development, vol.4, no.1, pp. 7-18, 2019.

[44] Antonio, J., Arevalo, T. "Financial and economic risk: Empirical evidence from the Spanish construction sector from 2003 to 2013". Universal Journal of Accounting and Finance, vol.9, no.2, pp. 145-159, 2021. DOI: 10.13189/ujaf.2021.090202.

[45]Lleshaj, L., Korbi, A. "Portfolio selection and VAR estimation: Evidence from Western Balkan countries". Universal Journal of Accounting and Finance, vol.8, no.4, pp. 92-102, 2020. 